\title{
ERYTHROCYTE PRESERVATION. II. A STUDY OF EXTRA- ERYTHROCYTE FACTORS IN THE STORAGE OF BLOOD IN ACID-CITRATE-DEXTROSE ${ }^{1}$
}

\author{
By BEVERLY WESCOTT GABRIO, ALEXANDER R. STEVENS, JR., AND \\ CLEMENT A. FINCH
}

\author{
(From the Department of Medicine, University of Washington School of Medicine, and the King \\ County Central Blood Bank, Seattle, Wash.)
}

(Submitted for publication June 8, 1953; accepted September 30, 1953)

The deterioration of the erythrocyte during storage has been shown to be unrelated to cell senescence as it occurs in vivo (1). Although the specific etiology of this degenerative process is unknown, it may be assumed that it is due to the failure of synthetic mechanisms vital to the cell. Possible causative factors include limited metabolites in the preserving media, the effect of stasis, the accumulation of toxic metabolic products within the cell, and the presence or accumulation of harmful substances in the media. The following studies were undertaken to evaluate the effect of the extra-erythrocyte environment on erythrocytes stored as whole blood in ACD (acid-citrate-glucose) preservative at $4^{\circ} \mathrm{C}$.

\section{MATERIALS AND METHODS}

Since storage has been shown to produce similar changes in the erythrocytes of the rabbit and human, (1) experiments were performed on both species. All manipulations of blood were performed with sterile precautions. When heparin was substituted for citrate in the preservative mixture, approximately $3 \mathrm{mg}$. of heparin per $100 \mathrm{ml}$. of blood were added daily. Glucose was present in all mixtures in a final concentration of 0.294 per cent.

Human blood containing excess leucocytes was prepared by removing the leucocyte layers from centrifuged units of blood and adding these to the blood to be studied. Blood samples with low leucocyte counts were obtained by repeated washings with 0.9 per cent $\mathrm{NaCl}$. Leucocytes at the liquid-cell interface were removed after each centrifugation. The erythrocytes were subsequently reconstituted with their original plasma. High-reticulocyte blood was prepared by repeated intracardiac bleedings of rabbits whose iron stores had been increased by the intravenous injection of saccharated iron oxide. ${ }^{2}$

1 This investigation was supported in part by research grants from the United States Atomic Energy Commission (Contract AT (45-1)-343) and United States Public Health Service (Contract H-1179 (C1).

2 We are indebted to Smith, Kline, and French Labora-
An hemolysate of human ACD blood was prepared by rapid freezing and thawing of the sample four times, and the stroma fraction was removed by the method of Pennell and Smith (2). When a blood sample containing hemolysate and stroma was centrifuged, preparatory to erythrocyte analysis, the stroma sedimented above the leucocyte layer and could be easily removed.

The post-transfusion survival of human erythrocytes was determined by the method of Young, Platzer, and Rafferty (3) with slight modifications. Baseline inagglutinable cell counts of 5,000 to 30,000 and of 4,000 to 15,000 per cu. mm., obtained with powdered anti-A and anti-M sera, ${ }^{3}$ respectively, were subtracted from all posttransfusion determinations. The theoretical inagglutinable cell count to be expected after transfusion, if no cells were destroyed, was determined by dividing the number of red cells injected by the blood volume $(\mathrm{ml}$.). The number of injected red cells was determined by the following formula: (red cells/cu. mm. $\times 10^{3}$ ) $\times$ the weight of injected blood $(\mathrm{Gm}$.) $\div 1.08$ (specific gravity of blood). The blood volume was measured by the T1824 dye technique (4). Following transfusion, the inagglutinable cell count was determined at 10 minutes, 1 day, 3 days, 5 days, and at subsequent intervals over a period of 45 days. These inagglutinable counts were plotted, and the slope of the values after the first day was extrapolated back to zero time. This extrapolated count divided by the theoretical inagglutinable cell count represents per cent survival. In these studies per cent survival thus represents the rapid phase of cell destruction which follows transfusion and which is usually complete within 24 hours. The reference point used for comparison is the survival of fresh whole blood. Employing the above calculations, five fresh blood transfusions averaged 95 per cent survival. Therefore, a correction factor of $1 / 95$ has been applied to all per cent survival data so that they relate to a fresh red cell survival of 100 per cent.

Measurements of phosphate partition, osmotic fragility, glucose utilization, post-transfusion survival of cells by the radioiron method, and radioactive iron processing have been previously described (1).

tories for the feojectin (saccharated iron oxide) used in these experiments.

8 Lederle Laboratories kindly supplied the lyophilized typing sera used in these studies. 
TABLE I

Comparison of storage media on phosphate changes in rabbit erythrocytes

\begin{tabular}{lrrrrr}
\hline \hline & \multicolumn{5}{c}{ mg. P/100 ml. erythrocytes } \\
\cline { 2 - 6 } $\begin{array}{c}\text { Storage } \\
\text { medium }\end{array}$ & Inorganic & Total & EH* $^{*}$ & DH* $^{*}$ & Non-H* \\
\hline ACD (R-1) & & & & & \\
0 & 7.89 & 89.39 & 11.50 & 7.28 & 62.72 \\
3 wks. & 43.53 & 70.22 & 4.32 & 3.79 & 18.58
\end{tabular}

Heparin-Glucose

$\begin{array}{lrrrrr}\text { (R-2) } & & & & & \\ \text { 0 } & 7.12 & 86.87 & 13.68 & 11.04 & 55.03 \\ \text { 3 wks. } & 48.08 & 72.12 & 5.89 & 5.40 & 12.75\end{array}$

Defibrinated

Blood-Glucose

$$
\text { (R-3) }
$$

3 wks.

7.70

99.51

$48.19 \quad 70.75$

16.84

6.10

$10.14 \quad 64.83$

$4.79 \quad 11.67$

* Fraction:

$\mathrm{EH}=$ easily hydrolyzable-

$\mathrm{DH}=$ difficultly hydrolyzable-

Non-H = non-hydrolyzable-

Predominant constituent: adenosine polyphosphates

hexose phosphates + adenylic acid

2,3-diphosphoglycerate

\section{RESULTS}

1. Effect of citrate. Heparin and defibrination were substituted for citrate in preventing coagulation of rabbit blood. The $\mathrm{pH}$ and the concentration of glucose were maintained similar to those found in blood stored in ACD. As indicated in Table I, the decrease in cellular organic phosphate compounds and the increase in inorganic phosphate proceeded at the same rate in the three types of storage media.

2. Effect of plasma. A comparison was made of human blood stored in the usual manner and blood from the same donor with weekly replacement of plasma with fresh ACD plasma. The changes in phosphate partition, reticulocyte maturation, osmotic fragility, and anaerobic glycolysis in erythrocytes which occurred during 28 days of storage were identical in the two systems. Furthermore, post-transfusion survival measurements of blood whose plasma was replaced weekly (Figure 1b) indicated a viability after four weeks of storage ( 65 per cent and 69 per cent) within the range found with ACD blood stored according to the regular procedure (40 to 70 per cent).

In a second series of experiments, the effect of "old" plasma on the storage of human red cells was tested. Blood was drawn into ACD, immediately centrifuged, and its plasma was replaced with ACD plasma removed from a blood which had been in storage for four weeks. The chemical measurements showed that the old plasma apparently did not accelerate nor inhibit the cellular alterations occurring over a period of three weeks storage, and viability studies indicated 87 per cent and 89 per cent survival after three weeks, values to be expected for this storage interval (Figure 1a).

Since it has been suggested by Reid and Ryan (5) that a dialyzable compound is present in human serum which has an inhibitory effect on the phosphate metabolism of erythrocytes, red cells were stored with plasma previously dialyzed with agitation for three hours against 0.9 per cent $\mathrm{NaCl}$. The rates of osmotic fragility and cellular phosphate changes in these cells during three weeks storage were similar to the control cells with nondialyzed plasma.

Similar studies in which plasma was replaced immediately by a mixture containing 10 per cent albumin, 1 per cent $\mathrm{NaCl}$, and 1 per cent glucose
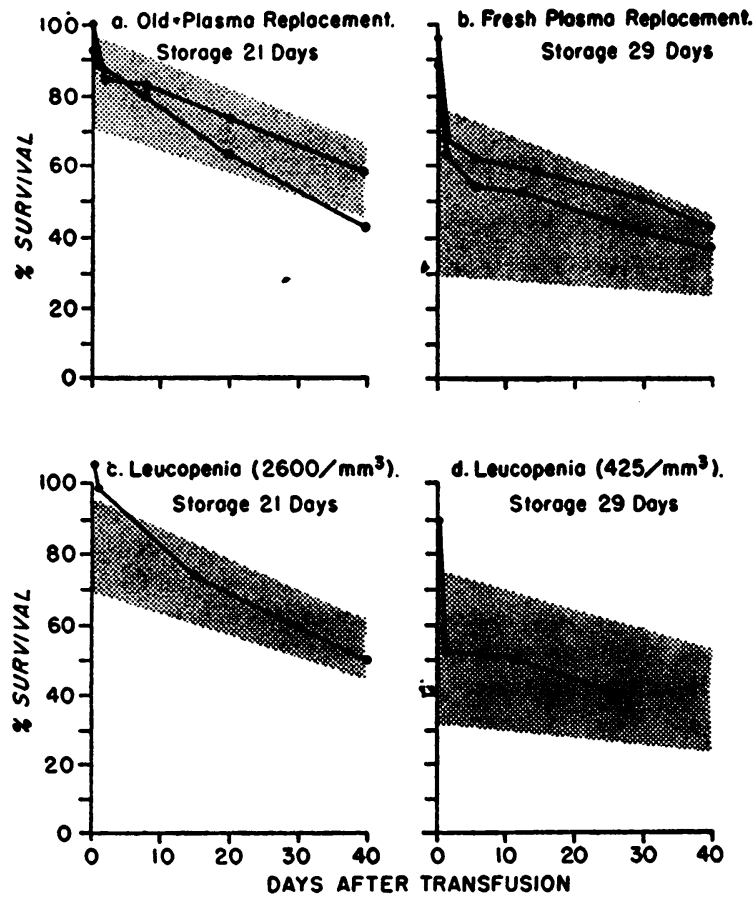

Fig. 1. Post-transfusion Survival Measurements of Stored Human Brood

The shaded areas represent the survival range as determined in our laboratory of normal blood stored in ACD for 21 or 29 days. 
TABLE II

The effect of leucocytes on human erythrocyte phosphates during storage

\begin{tabular}{|c|c|c|c|c|c|}
\hline \multirow{2}{*}{$\begin{array}{l}\text { White count } \\
\text { (cells/cu. mm.) } \\
\text { and days storage }\end{array}$} & \multicolumn{5}{|c|}{ mg. $P / 100 \mathrm{ml}$. erythrocytes } \\
\hline & Inorganic & Total & EH* & $\mathrm{DH}^{*}$ & Non-H* \\
\hline $\begin{array}{r}700 \\
0 \text { day } \\
24 \text { day }\end{array}$ & $\begin{array}{r}4.81 \\
31.50\end{array}$ & $\begin{array}{l}65.83 \\
48.27\end{array}$ & $\begin{array}{l}9.50 \\
4.91\end{array}$ & $\begin{array}{l}5.41 \\
1.01\end{array}$ & $\begin{array}{l}46.11 \\
10.85\end{array}$ \\
\hline $\begin{array}{l}83,000 \\
0 \text { day } \\
23 \text { day }\end{array}$ & $\begin{array}{r}5.82 \\
28.35\end{array}$ & $\begin{array}{l}66.20 \\
52.40\end{array}$ & $\begin{array}{r}14.81 \\
8.10\end{array}$ & $\begin{array}{l}8.61 \\
5.06\end{array}$ & $\begin{array}{l}36.20 \\
10.89\end{array}$ \\
\hline
\end{tabular}

* See legend, Table I.

at $\mathrm{pH} 7.2$ as a suspending solution for erythrocytes during storage showed changes in red cell phosphates identical with those of regular ACD storage over a period of 31 days.

3. Effect of leucocytes and reticulocytes. The influence of such metabolically active cells as leucocytes and reticulocytes upon the progression of the storage lesion in erythrocytes was studied.

Changes in phosphate partition were measured in a group of patients with white counts elevated to 83,000 cells per cu. $\mathrm{mm}$. and in patients with agranulocytosis, with counts as low as 700 cells per cu. mm. Illustrative data on two of these bloods are shown in Table II. Such extremes of white count, whether involving granulocytic or lymphocytic cell types, had no significant effect on the rate or degree of erythrocyte phosphate changes. Post-transfusion survival determinations

TABLE III

The effect of reticulocytes on rabbit erythrocyte phosphate alterations during storage

\begin{tabular}{|c|c|c|c|c|c|c|}
\hline \multirow[b]{2}{*}{ Sample } & \multirow[b]{2}{*}{$\begin{array}{c}\text { Days } \\
\text { storage }\end{array}$} & \multicolumn{5}{|c|}{ mg. $\mathrm{P} / 100 \mathrm{ml}$. erythrocytes } \\
\hline & & $\begin{array}{l}\text { Inor- } \\
\text { ganic }\end{array}$ & $\begin{array}{c}\text { Or- } \\
\text { ganic }\end{array}$ & EH* & $\mathrm{DH}^{*}$ & Non- $\mathrm{H}^{*}$ \\
\hline $\begin{array}{l}\text { Normal } \\
3.0 \% \text { retics }\end{array}$ & $\begin{array}{r}0 \\
22\end{array}$ & $\begin{array}{r}7.35 \\
45.18\end{array}$ & $\begin{array}{l}81.18 \\
22.46\end{array}$ & $\begin{array}{r}10.44 \\
1.34\end{array}$ & $\begin{array}{l}6.45 \\
3.29\end{array}$ & $\begin{array}{l}64.29 \\
17.83\end{array}$ \\
\hline $\begin{array}{l}\text { High retic } \\
20.6 \% \text { retics }\end{array}$ & $\begin{array}{r}0 \\
22\end{array}$ & $\begin{array}{r}8.51 \\
53.84\end{array}$ & $\begin{array}{l}98.58 \\
24.55\end{array}$ & $\begin{array}{r}17.91 \\
1.47\end{array}$ & $\begin{array}{l}8.86 \\
5.32\end{array}$ & $\begin{array}{l}71.81 \\
17.76\end{array}$ \\
\hline $\begin{array}{c}\text { Normal: High } \\
\text { retic }=1: 1 \\
12.4 \% \text { retics }\end{array}$ & $\begin{array}{r}0 \\
22\end{array}$ & $\begin{array}{r}8.41 \\
49.06\end{array}$ & $\begin{array}{l}87.53 \\
26.17\end{array}$ & $\begin{array}{r}12.46 \\
1.81\end{array}$ & $\begin{array}{l}9.42 \\
4.19\end{array}$ & $\begin{array}{l}65.65 \\
20.71\end{array}$ \\
\hline $\begin{array}{c}\text { Normal: High } \\
\text { retic }=3: 1 \\
10.8 \% \text { retics }\end{array}$ & $\begin{array}{r}0 \\
22\end{array}$ & $\begin{array}{r}7.89 \\
43.53\end{array}$ & $\begin{array}{l}81.50 \\
25.51\end{array}$ & $\begin{array}{r}11.50 \\
1.82\end{array}$ & $\begin{array}{l}7.28 \\
4.17\end{array}$ & $\begin{array}{l}62.72 \\
19.52\end{array}$ \\
\hline
\end{tabular}

* See legend, Table I. of two normal bloods from which most of the leucocytes had been removed on the day of phlebotomy (counts of 2,600 cells per cu. mm. and 425 cells per $\mathrm{cu}$. $\mathrm{mm}$.) showed 95 per cent viability after three weeks of storage and 54 per cent after four weeks (Figure 1c, d), values within the range of unaltered ACD blood. Similar in vitro and in vivo evidence was obtained with rabbit erythrocytes prepared with low and high leucocyte counts.

In an attempt to evaluate further the importance of competition for essential nutrients, large numbers of reticulocytes were mixed with normal blood. Effects of storage on the phosphate partition of the cells in blood mixtures containing variable amounts of reticulocytes are shown in Table II. While higher values for cellular adeno-

TABLE IV

The effect of hemolysates on human erythrocyte phosphates during storage

\begin{tabular}{cccccc}
\hline & \multicolumn{5}{c}{ mg. P/100 ml. erythrocytes } \\
\cline { 2 - 6 } & Inorganic & Total & $\mathrm{EH}^{*}$ & $\mathrm{DH}^{*}$ & Non-H* \\
\hline 1 day & 5.03 & 48.68 & 7.54 & 4.36 & 31.75 \\
$\begin{array}{c}\text { Control blood } \\
\text { Blood + Hem. } \\
\text { with stroma }\end{array}$ & 5.29 & 51.46 & 7.67 & 4.38 & 34.12 \\
$\begin{array}{c}\text { Blood + Hem. } \\
\text { w/o stroma }\end{array}$ & 6.34 & 48.38 & 7.67 & 3.98 & 30.39 \\
$\begin{array}{c}\text { w3 day } \\
\text { Control blood } \\
\text { Blood + Hem. } \\
\text { with stroma }\end{array}$ & 27.75 & 40.66 & 3.98 & 2.34 & 6.59 \\
$\begin{array}{c}\text { Blood + Hem. } \\
\text { w/o stroma }\end{array}$ & 28.26 & 40.00 & 3.33 & 1.16 & 7.25 \\
\hline
\end{tabular}

* See legend, Table I.

sine polyphosphates and 2,3-diphosphoglycerate were found initially in the reticulocyte-laden blood, the values of all of the samples at three weeks were essentially the same. Normal rabbit blood, tagged with radioiron, to which large numbers of reticulocytes had been added (final concentration of 20 per cent reticulocytes) showed a survival of 65 per cent and 70 per cent after three weeks of storage as compared with a viability of 63 per cent and 60 per cent of the same blood stored for three weeks without reticulocytes.

4. Effect of hemolysis. Hemolysates of whole blood with and without stroma were added to human blood and were shown to have little effect on the progression of erythrocyte phosphate changes (Table IV). It appeared that through 12 days 
of storage, the presence of an hemolysate containing stroma somewhat retarded the breakdown of the cellular organic phosphates, although after 23 days this effect was less marked.

\section{DISCUSSION}

The problem of blood preservation is the problem of the maintenance of a complex metabolic unit, the erythrocyte, in a limited in vitro environment. Lower temperatures decrease the rate of metabolic processes and therefore the requirements of the erythrocytes. Translated into terms of survival, cells preserved at $37^{\circ} \mathrm{C}$. in $\mathrm{ACD}$ maintain viability for only one to two days, at $4^{\circ} \mathrm{C}$. for three to four weeks, and at subzero temperatures possibly for several months (6). The present series of investigations is concerned, however, with a delineation of the storage damage and its etiology regardless of the temperature. The dependence of the metabolizing erythrocyte upon glucose has been clearly established, and an adequate supply of glucose in the studies reported herein eliminate this from further consideration. Inasmuch as viability and phosphate partition measurements on erythrocytes equilibrated during storage with oxygen, nitrogen, or air gave similar results, the latter gas environment was considered satisfactory and was used throughout the experiments. The present study was undertaken to determine 1) if plasma substances other than glucose could be shown to have demonstrable effect in supporting erythrocyte metabolism during storage, or 2) if harmful substances are present or accumulate in the plasma as a result of cell metabolism or breakdown or plasma-cell interaction during storage.

It has been shown that the replenishment of stored blood with fresh plasma, and storage with dialyzed plasma, "aged" plasma, or an albuminglucose- $\mathrm{NaCl}$ solution had no demonstrable effect on cell preservation. These observations do not indicate the presence of other important available nutrients in plasma which become depleted during storage and thereby contribute to storage damage. This is consistent with the finding that erythrocytes tolerate preservation in a synthetic medium nearly as well as in whole blood (7). Although it has not been demonstrated that the plasma contains metabolites other than glucose for red cell preservation, this in no way excludes the role of the plasma in vivo as a transport mechanism for such essential metabolites between the erythrocyte and other body tissue.

When blood coagulation was prevented by means other than citrate, no improvement was found in storage characteristics of the red cell. Thus, although citrate may bind plasma metals other than calcium, there is no evidence that this is deleterious to stored blood. Likewise, leucocytes, reticulocytes, hemolysates, and "aged" plasma did not accelerate the degenerative process in the red cell. It is not surprising that the concentration of metabolic products of the cellular elements does not appear to cause the storage lesion, since previous studies (7), using large volume diluents, have not shown improved erythrocyte preservation.

The evidence indicates that these alterations in the extra-erythrocyte environment have little effect on the erythrocyte during storage and would rather focus attention on the intrinsic metabolic failure of the erythrocyte during storage.

\section{SUMMARY}

The role of the extra-erythrocytic environment in the production of the storage lesion in the erythrocyte has been investigated. Damage to the stored erythrocyte has been measured by osmotic fragility, phosphate partition, and viability after transfusion. There was no evidence of a deleterious effect of citrate, plasma, leucocytes, reticulocytes or hemolysates. Throughout there was a remarkable consistency in the appearance of the chemical changes measured and in loss of viability of the erythrocyte. It would appear that when blood is stored at 0 to $4^{\circ} \mathrm{C}$. in ACD, the storage lesion in the erythrocyte bears little relation to its surrounding medium.

\section{ACKNOWLEDGMENT}

The authors wish to acknowledge the valuable technical assistance of Mrs. Alice Rupen, Mrs. Olga Matson, and Miss Frances Vokracek.

\section{REFERENCES}

1. Gabrio, B. W., and Finch, C. A., Erythrocyte preservation. I. The relation of the storage lesion to in vivo erythrocyte senescence. J. Clin. Invest., 1954, 33, 000.

2. Pennell, R. B., and Smith, W. E., Preparation of stabilized solutions of hemoglobin. Blood, 1949, 4, 380 . 
3. Young, L. E., Platzer, R. F., and Rafferty, J. A., Differential agglutination of human erythrocytes. J. Lab. \& Clin. Med., 1947, 32, 489.

4. Gibson, J. G., 2nd, and Evelyn, K. A., Clinical studies of the blood volume. IV. Adaptation of the method to the photoelectric microcolorimeter. J. Clin. Invest., 1938, 17, 153.

5. Reid, A. F., and Ryan, E. B., Properties of a red cell metabolism regulator. Federation Proc., 1950, 9, 218.
6. Mollison, P. L., Sloviter, H. A., and Chaplin, H., Survival of transfused red cells previously stored for long periods in the frozen state. Lancet, 1952, 263, 501.

7. Gibson, J. G., 2nd, Evans, R. D., Aub, J. C., Sack, T., and Peacock, W. C., The post-transfusion survival of preserved human erythrocytes stored as whole blood or in resuspension, after removal of plasma, by means of two isotopes of radioactive iron. J. Clin. Invest., 1947, 26, 715. 